\title{
Problems of qualification of crimes prescribed in articles 207.1, 207.2 of the Criminal Code of the Russian Federation
}

\author{
Maksim Viktorovich Bavsun ${ }^{1 *}$, Kirill Valerievich Vishnevetskii ${ }^{2}$, Aleksandr Nikolaevich \\ Ignatov $^{3}$, Aleksey Aleksandrovich Kashkarov ${ }^{3}$, and Vandan-Ish Amarsanaa ${ }^{4}$ \\ ${ }^{1}$ Saint Petersburg University of the Ministry of Internal Affairs of Russia, Saint Petersburg, Russia \\ ${ }^{2}$ Krasnodar University of the Ministry of Internal Affairs of Russia, Department of Criminal Law and \\ Criminology, Krasnodar, Russia \\ ${ }^{3}$ Crimean Branch of the Krasnodar University of the Ministry of Internal Affairs of Russia, \\ Department of Criminal Law and Criminology, Simferopol, Russia \\ ${ }^{4}$ University of Internal Affairs of Mongolia, Institute of Police, Department of Crime Investigation \\ Methodology, Ulaanbaatar, Mongolia
}

\begin{abstract}
The article is devoted to the problems of qualification of crimes prescribed by Articles 201.1 and 207.2 of the Criminal Code of the Russian Federation. The article analyzes the practice of the Supreme Court of the Russian Federation, aimed at clarifying the new provisions of the Criminal Code of the Russian Federation, as well as requirements for their practical implementation. Purpose: to identify the advantages and disadvantages of criminal-legal regulation of disseminating knowingly false information that poses a danger to the life or health of people and their safety in the pandemic. Methods: the study of the relevant norms using the systemic method, general scientific methods (structural-functional analysis, comparison, logical method, and content analysis of the practice of courts). Main results: the study made it possible to identify the advantages and disadvantages of the norms providing for criminal liability for the public dissemination of knowingly false information regarding the circumstances that pose a threat to the life and safety of citizens and the public dissemination of knowingly false socially significant information, which entailed grave consequences, as well as separate qualification errors in judicial and investigative practice that arose at the initial stage of their implementation. Conclusions and substantiation of the novelty of the work: the insufficient effectiveness of the existing approach to the problems of legal assessment of crimes is substantiated, which provides for responsibility for the public dissemination of knowingly false information regarding the circumstances that pose a threat to the life and safety of citizens and the public dissemination of knowingly false socially significant information, which entailed grave consequences, and the ways of solving the specified problems are proposed. At the same time, it is noted that the changes in legislation, especially such as criminal one, should be the result of targeted criminological analysis, with an appropriate criminological (and not spontaneous action - reflection on what is happening) forecast of the situation development. The authors
\end{abstract}

* Corresponding author: kafedramvd@ mail.ru 
highlight the unprecedented character of the measures taken by the state and the need to cancel them when external factors change, which provoked the changes in the criminal-legal regulation of public relations.

Keywords: legal regulation, coronavirus, false information, dissemination

\section{Introduction}

The rapid transformation of public relations caused by the pandemic situation and the emergence of new threats in this connection led to changes in the criminal legislation. First of all, this concerns the inclusion of new articles in it, aimed at regulating the issues of responsibility for violating the new regime in the current conditions, as well as the dissemination of information that can lead to a state of panic among the population. Given the uniqueness of this kind of innovations, their analysis is considered to be extremely important from the point of view of the subsequent consideration of the experience gained in similar situations. This study is aimed at identifying patterns in the state's response to the emergence of new threats and their timely handling by criminal-legal means.

\section{Formulation of the problem}

Both articles were included in the Criminal Code of the Russian Federation in early 2020 against the background of the coronavirus pandemic that struck the whole world, which was a defensive reaction of the state to potential threats of the dissemination of any information capable of destabilizing public relations [1, pp. 1-20]. This thesis is confirmed by the note to Art. 207.1 of the Criminal Code of the Russian Federation, which lists a wide range of situations of a hazardous nature: from natural and technogenic nature to other disasters $[2, \mathrm{p}$. 29]. The use of such an indefinite category allows asserting that the position of the legislator in this case is based on the desire to maximize the coverage of those threats that do not yet exist, but which may arise in the future.

Article 207.1 of the Criminal Code of the Russian Federation contains a formal structure of a crime, suggesting that there is only a threat to the life and safety of citizens as a result of public dissemination of knowingly false information under the guise of reliable messages. While Art. 207.2 of the Criminal Code of the Russian Federation has a material structure, including quite specific consequences, which are already in the disposition of the norm, in the form of harm to health of any severity, and in the qualified structure - the death of the victim or other grave consequences [3, pp. 178-179]. Meanwhile, the objective side of both legislative structures in terms of describing a socially dangerous act almost coincides, which allows making an assumption about the similarity of their legal nature and the real possibility of their presentation within the framework of a single legal prescription. It is already obvious that in practice [4, p. 82] serious questions will arise in connection with the interpretation of the category of "socially significant information" and the establishment of a causal relationship between actions to disseminate it and the onset of the above-mentioned consequences (Article 207.2 of the Criminal Code of the Russian Federation) [5, p. 234].

In this regard, in fact, forcedly, the Supreme Court of the Russian Federation should have taken an active position, which in its review No. 1 dated already April 21, 2020 on certain issues of judicial practice related to the application of legislation and measures to counter the spread of coronavirus infection gave the following recommendations: "...the information regarding the circumstances posing a threat to the life and safety of citizens, and (or) regarding the measures taken in this regard to ensure the safety of the population and territories, as well as techniques and methods of protection from the indicated circumstances, can be attributed to socially significant information. 
Taking this into account, the public dissemination of knowingly false information under the guise of reliable messages, which is referred to in the note to Article 207.1 of the Criminal Code of the Russian Federation, which, through negligence, caused harm to human health, his or her death or other serious consequences, is qualified according to the relevant part of Article 207.2 of the Criminal Code of the Russian Federation. If, as a result of these actions, the specified consequences did not occur, the act should be qualified according to Article 207.1 of the Criminal Code of the Russian Federation" [6]. Thus, the information regarding circumstances that pose a threat to the life and safety of citizens is proposed to be considered as a variety of socially significant information and to qualify it as knowingly false dissemination under Art. 207.1 or Art. 207.2 of the Criminal Code of the Russian Federation only depending on the presence or absence of the above-mentioned consequences.

\section{$3 \quad$ Results and discussion}

The authors believe that with the appearance of the structures indicated in the Criminal Code of the Russian Federation, a unique situation has developed when, in fact, the presence of one subject of crime (information, knowingly false in one case and knowingly false but socially significant in another case, taking into account the presence of public importance in both cases), the qualification is conducted under different articles of the criminal law [7, $p$. $189 ; 8$, p. 99]. The approach as a whole is not typical for the Russian legislator, which is most likely of a spontaneous nature, due to the unexpectedness and swiftness of the appearance of fundamentally new threats in society. Currently, something similar can be observed (with a great deal of convention) in Art. Art. 110 and Art. 110.1 of the Criminal Code of the Russian Federation, where it is a question of causing someone to commit suicide or inducement to it (respectively). Despite the reservation made by the legislator in the disposition of Art. 110.1 of the Criminal Code of the Russian Federation on the absence of signs of causing someone to commit suicide, in fact, it is not so easy to separate this from inducement, since the directly performed actions at the same time can correspond to both the first and the second act. Actually, this is directly stated in Review 2 of the Supreme Court of the Russian Federation, which notes that "One of the main conditions for the onset of responsibility under Art. 207.1 or Art. 207.2 of the Criminal Code of the Russian Federation is the dissemination of knowingly false information under the guise of reliable one". Thus, the criminal-legal regulation of one social relationship is conducted, in fact, in two norms. The same thing happens in the authors' case, with the only difference that it is not about the sign of the objective side, but about the subject of the crime. Meanwhile, the uniqueness of the new norms and explanations to them lies in the fact that the commission of one crime (Art. 207.1 of the Criminal Code of the Russian Federation) can act as one of the conditions (upon the occurrence of a certain consequence) of bringing to criminal liability under another article of the Criminal Code of the Russian Federation (Article 207.1 of the Criminal Code of the Russian Federation). This aspect is perhaps one of the most controversial in the newly emerged norms, indicating some uniqueness and novelty of the legislator's approach to solving the issue of comprehensive regulation of responsibility for a newly emerged socially dangerous act. Although, undoubtedly, the novelty and randomness in the activities of any legislator of any country can accompany each other, and not be mutually exclusive.

In this case, it is not about the flaws in the legislative technique or the redundancy of criminal-legal regulation, which are undoubtedly present, but about the newly created precedent and the need for its corresponding doctrinal analysis, regardless of the reasons for its appearance in law.

Tellingly, literally a week after Review 1, the Supreme Court of the RF elaborated Review 2 (April 30, 2020), in which independent attention is paid to the definition of knowingly false information regarding the circumstances of the spread of coronavirus infection in the territory 
of the Russian Federation. Under this, as noted in the document, one should understand information that initially does not correspond to reality in relation to the above-mentioned circumstances, of which the person who disseminated such information was aware in advance [9]. The comment made on the subject of the crime, on the one hand, makes it possible to clarify the signs of what actually relates to the subject to be proven, and on the other hand, formed the basis for additional contradictions regarding the delimitation of the two structures. This is largely due to the fact that the noted clarification does not highlight the key points between knowingly false information (Article 207.1 of the Criminal Code of the Russian Federation) and knowingly false socially significant information (Article 207.2 of the Criminal Code of the Russian Federation). For the law enforcer, the distinction between two in fact essentially identical types of information still remains at the level of an unsupported assessment, which with a high degree of probability will entail either errors in judicial and investigative practice, or, more likely, the absence of such at all. Its paralysis, it seems, will be caused precisely by the lack of a clear idea of what needs to be proven, due to the absence of at least an approximate border between the categories that are mentioned in the new norms of the Criminal Code of the Russian Federation. Taking into account that in this case, it concerns not just delimitation but also the existence of a real possibility of a legal assessment of what was done within the framework of one article of the Criminal Code of the Russian Federation based on the signs of a different structure, the above-mentioned explanation does not help much in solving this problem. It seems that the originality of the situation cannot be removed at any of the levels of interpretation, it is laid down directly in the text of the law and requires the intervention of the legislator, and not the law enforcer, even of the highest level.

\section{Conclusion}

The norms provided for by Art. 201.1 and Art. 207.2 of the Criminal Code of the Russian Federation should be, first of all, criminologically substantiated, and then, legally competently constructed in the legislative fabric.

Meanwhile, this is not the most difficult situation in terms of countering new threats by means of a criminal-legal nature. The above-mentioned circumstances truly complicate it, but they are not the main ones. The problem is complex and to a lesser extent depends on technical and legal structures $[10$, p. $284 ; 11$, p. 711; 12, p. 33; 13, p. 5; 14, p. 22]. Obviously, according to a fair observation by Steshich, in addition to sectoral legislation, a radical revision of the entire internal and external strategy is required nowadays in this direction of the absolute majority of states. All this requires, first of all, a criminological analysis, with the subsequent implementation of a set of measures that should be developed on its basis [15, p. 34]. Political will should not be limited to making changes in criminal, administrative, or any other legislation. Moreover, such changes should be the result of a purposeful criminological analysis, with an appropriate criminological (and not spontaneous action reflection on what is happening) forecast, the development of a situation in the absence or, conversely, the presence of relevant norms in the law. Due to these factors, the opinion of the legislator can be formed regarding, first, the expediency of the very decision to improve legal regulation, and second, the technical component of their decision, when the quality of the means that are required for this will depend on the degree of clarity of understanding the threat.

Scientific novelty consists in that the article states the authors' position on the problem of law enforcement of the norms provided for by Art. 201.1 and Art. 207.2 of the Criminal Code of the Russian Federation, as well as their criminological substantiation.

Practical significance lies in the possibility of increasing the efficiency of the mechanism for countering socially dangerous manifestations associated with the dissemination of 
knowingly false information regarding the circumstances posing a threat to the life and safety of citizens and the public dissemination of knowingly false socially significant information, which entailed grave consequences by means of implementing criminologically justified and legally competently constructed criminal-legal norms.

\section{References}

1. R. Broadhurst, P. Grabosky, M. Alazab, S. Chon, Int. J. Cyber Criminol. 8(1), 1-20 (2014)

2. T. Kirchengast, The victim in criminal law and justice (Palgrave MacMillan, New York, 2006)

3. J. Froestad, Criminology: re-imagining security and risk, in P. Bourbeau (ed.), Security: Dialogue across Disciplines, 177-195 (Cambridge University Press, Cambridge, 2016)

4. P.G. Cassell, N.J. Mitchell, B.J. Edwards, J. Crim. Law Criminol. 104(1), 59-103 (2014)

5. M.V. Bavsun (ed.), Ugolovnoe pravo. Osobennaya chast [Criminal law. Special part] (Omsk Academy of the Internal Affairs of Russia, Omsk, 2020)

6. Supreme Court of the Russian Federation, Obzor No. 1 po otdelnym voprosam sudebnoi praktiki, svyazannym s primeneniem zakonodatelstva i mer po protivodeistviyu rasprostraneniyu na territorii Rossiiskoi Federatsii novoi koronavirusnoi infektsii (COVID-19) [Review of certain issues of judicial practice pertaining to application of legislation and measures aimed at preventing the spread of the novel coronavirus infection (COVID-19) in the Russian Federation, No. 1] (2020). Accessed on: March 19, 2021. [Online]. Available:

http://www.supcourt.ru/press_center/news/28855/

7. J. Rawls. A theory of justice (Harvard University Press, Cambridge, 1979)

8. S. Alshehri, The right to a fair trial within a reasonable time in criminal cases: A comparative study between Saudi Arabia and the requirements of the European Convention on Human Rights, using English law as an exemplar (University of Dundee, Dundee, 2017)

9. Supreme Court of the Russian Federation, Obzor No. 2 po otdelnym voprosam sudebnoi praktiki, svyazannym s primeneniem zakonodatelstva i mer po protivodeistviyu rasprostraneniyu na territorii Rossiiskoi Federatsii novoi koronavirusnoi infektsii (COVID-19) [Review of certain issues of judicial practice pertaining to application of legislation and measures aimed at preventing the spread of the novel coronavirus infection (COVID-19) in the Russian Federation, No. 2] (2020). Accessed on: March 19, 2021. [Online]. Available: http://www.supcourt.ru/press_center/news/28883/

10. O. Zaytsev, A. Yepihin, Internal Security, 8(1), 283-291 (2016). https:doi.org//10.5604/20805268.1231600

11. E.G. Popkova, Ubiquitous computing and the Internet of Things: Prerequisites for the development of ICT (Springer, Berlin, 2019)

12. D. Black, D. Hayman, The changing nature of crime and criminal investigations (Washington, 2018)

13. A.V. Nikulenko, Obstoyatelstva, isklyuchayushchie prestupnost deyaniya: kontseptualnye osnovy ugolovno-pravovoi reglamentatsii [Circumstances excluding criminality of the act: conceptual foundations of criminal-legal regulation], $\mathrm{PhD}$ thesis 
(Saint Petersburg University of the Ministry of Internal Affairs of Russia, Saint Petersburg, 2019)

14. S.F. Milyukov, A.V. Nikulenko, Prichinenie vreda pri zaderzhanii litsa, sovershivshego obshchestvenno opasnoe deyanie [Causing harm during the arrest of a person who has committed a socially dangerous act] (Yuridicheskii tsentr, Saint Petersburg, 2020)

15. E.S. Steshich, Vestnik of the Saint Petersburg University of the Ministry of Internal Affairs of Russia, 4 (2020) 